\title{
Women's Leadership in Asta Brata
}

\author{
Budiana Setiawan ${ }^{1}$ \\ \{budianasetiawan@gmail.com ${ }^{1}$ \} \\ Center for Policy Research, Board for Research and Development and Books, Ministry of Education \\ and Culture
}

\begin{abstract}
Women are often considered inappropriate person to lead a society because most people believed if they lack leadership characteristics. Leadership is synonymous with masculine traits and is only owned by men. However, in historical fact, from time to time there have always been women leaders, both in Nusantara and in other states in the world. Even in modern era, many women have become leaders, from level regional to president and prime minister. All of the women do not lose their feminine traits, such as: graceful, humanistic, maternity, doing by feelings, and so on. In this regard, Javanese have a concept of leadership, that is called Asta Brata (eight traits of leadership), which was inherited from Hinduism. How does the application of Asta Brata's teachings in leadership traits of someone? Does the leadership traits have to be absolutely masculine? Is there actually a harmony between masculine and feminine traits in the leadership teaching of Asta Brata? The research is doing by desk research/ literature study). The method of data collection is used through literature that is relevant to the problem. The results showed that the good characters of leadership in Asta Brata's teachings are manifested in figures of gods, which are personifications of nature, namely: Surya, Candra, Kartika, Angkasa, Bayu, Samudra, Agni, and Pertiwi. The eight leadership traits reflect dualities, namely masculine and feminine. Masculine aspects of leadership are found in Surya (sun), Angkasa (sky), Bayu (wind), and Agni (fire). Meanwhile, feminine aspects of leadership are found in Kartika (star), Candra (moon), Samudra (ocean), and Pertiwi (land). Thus, the teachings of Asta Brata show equality between women and men in order to become leaders of a society.
\end{abstract}

Keywords: women, leadership, Asta Brata teachings, duality, gods.

\section{Introduction}

The discourse on leadership of women in a society is always to be an endless topic of discussion. The question that always arise, "Is it proper for women to be leaders of a society?". Moreover, from a religious viewpoint. As believed by most people, women are considered unworthy of leadership because they do not have leadership traits, such as: strict, firm, strong, brave, dignified, feared and respected by opponents, etc. Women are also considered to have weak traits when leading, such as: emotional, unlogical thinking, cowardice, etc.

Many leaders of religion deny women's leadership by using religion's propositions as the reasons. Many of them are cited verses in the holy book, which are believed to be the words of God through His messengers, to justify their opinion that women are not worthy to be leaders of a society. Based on their belief in religion, they believe that women are destined not to have leadership traits. However, if this is the case, the leaders of religion should admit that in their religion, women have a subordinate position, under the leadership of men. In this way, women 
naturally remain unequal to men. Oddly enough, they still claim that their religion teaching if women have the same level as men.

Although many religion leaders refuse women's leadership, in historical reality, there were many women leaders from time to time, both in Nusantara and in other parts of the world. In the history of Nusantara (which is manifesting to be Indonesia now), there have been raised women leaders. In the Hindu-Buddhist era, there was Queen Sima from Kalingga Kingdom; Queen Tribhuwana Tunggadewi and Queen Suhita from Majapahit Kingdom; Queen Wa Kaa Kaa, the founder of Buton Kingdom, which was passen on by her daughter, Queen Bolawambona; etc.

During the Islamic period, Aceh Sultanate was ever ruled by four sultanah (female sultans), namely: Sultanah Tajul Alam Safiyatuddin, Sultanah Nurul Alam Nahiyatuddin, Sultanah Inayat Syah Zakiyatuddin, and Sultanah Kamalat Shah. Meanwhile, Samudera Pasai Kingdom was ever ruled by two queens, namely: Nur Ilah and Nahrasiyyah (Putri, 2017).

In era of the Republic of Indonesia, we have many women who ruled regions also. For example, the head of regency/ municipality, there are Tri Rismaharini (Mayor of Surabaya Municipality, East Java Province), Airin Rachmi Diany (Mayor of South Tangerang Municipality, Banten Province), Ni Putu Eka Wiryastuti (Regent of Tabanan Regency, Bali Province), Karolin Margret Natasa (Regent of Landak Regency, West Kalimantan Province), Indah Putri Indirani (Regent of North Luwu Regency, South Sulawesi Province), and others. There are at least two female governors also, namely: Ratu Atut Chosiyah (Governor of Banten Province 2007-2014), and Khofifah Indar Parawamsa (Governor of East Java Province), and a woman president, Megawati Soekarno Putri (2001-2004).

Interestingly, the women who are leaders of region do not lose their feminine characteristics, and turn to be masculinity, such as: decisive, harsh, strong, brave, and so on. They fixed as women generally, with their traits, such as:

graceful, humanistic, maternity, doing by feelings, and so on. In fact, they often seen do not hesitate to cry in public area when their hearts are touched by something, both saddly (for example: seeing people who are poor or experiencing disasters) or happy (for example: her region is rewarded for the achievements). Even though, crying easly is a weepy attitude and is considered to be against for good attitude leadership.

In this regard, Javanese people have a concept of good leadership, namely Asta Brata, which is inherited from Hinduism. Returning to the above statement, if there are many women leaders who do not lose their feminine traits in leading their region, how is Asta Brata's teaching in valuing to leadership traits of someone? Does the leadership have to be absolutely masculine character? The other side, is there actually a harmony between masculine and feminine character? This view is needed to provide an explanation about "worthy or not worthy" for a woman to be a leader for a society in the modern era, especially from point of view of Javanese society.

\section{METHOD}

This paper is a qualitative. It is a type of desk research/ literature study. The data collection method that used is through literature study as an effort to collect data that is relevant to the problem of the study. Literature study include books, papers, and other sources from printed and electronic/ internet media. In this case, literature sources are mostly obtained 
through electronic/ internet media than printed media, because they are relatively easy to obtain in a brief time, but the validity data is responsibility.

In the study, analysis technique that used is content analysis. According to H. D. Lasswell et al., content analysis records symbols or messages systematically, then gives them an interpretation (Lasswell et al. 1952). Meanwhile, according to O. R. Holsti, the content analysis method is a technique for drawing conclusions by identifying various special characteristics of a message objectively, systematically, and generally (Holsti, 1969). In detail, it is described as follows: (1) objective means that according to rules or procedures that will consistently produce similar conclusions when examined by different researchers, (2) systematic means that categorization is carried out according to consistently applied rules which consist of guaranteeing selection and data coding, so there is no bias, (3) Generalist means that the research findings have theoretical references, so that the information can be linked to other attributes of the document and has high theoretical relevance.

According to Nasution, data analysis is a process of compiling data so that it can be interpreted. While data interpretation means give a meaning to analysis, explaining patterns or categories, looking for relationships between various concepts (Nasution, 1996). According to Sugiyono, data analysis is process of searching and arranging data systematically, that obtained from data collection by organizing data into categories, describing them into units, synthesizing, arranging into patterns, choosing which are important and what will be studied, and finally make conclusions. So, the result can be understood easily by theirselves and others (Sugiyono, 2008: 335).

In this case aspects in content analysis used include: characteristics of nature in Asta Brata which are personified in figures of a gods (masculine) or a goddess (feminine), duality relationship of those natural characteristics, and tendency to give names of natural traits in both girls and boys.Then, the data that have been obtained are analyzed to be able to draw conclusions.

\section{LEADERSHIP ACCORDING HINDUISM AND ASTA BRATA TEACHINGS}

\subsection{Position of Women to Men in Hinduism}

Before discussing leadership traits, it is necessary to know position of women to men in perspective of Hinduism firstly. In Manawa Dharmasastra Chapter I, Verse 32, is mentioned (Pudja and Sudharta, 2003):

Dwidha krtwatmano deham

Ardhena puruso'bhawat

Ardhena nari tasyam sa

Wirayama smrjat prabhuh

meanings:

By dividing Himself/ into a part of male and a part of female (ardha nari), He creats Wiraja from the woman.

Based on the verse, it can be seen that God also "divides Himself" into a part of male and a part of female, so the two are "equally divided". This means that both man and woman are 
God's creation, there is nothing better and worse, higher and lower. God creates man and woman as a balance. A harmony will be created if men and women can be united. Like mountains and oceans, even though the places are far apart, both of them are still united and in balance to maintain harmony of the world.

Furthermore, in Manawa Dharmasastra Chapter I, Verse 21 is mentioned (Pudja and Sudharta, 2003):

Sarwesam tu sa namani

Karmanica prthak prthak

Wedaçabdebhya ewadau

Prthak samsthaçca nirmame

Meaning:

In fact He has predetermined names of deeds and characteristics of all of His creations from the beginning as words in the Vedas.

Based on the verse, it can be seen that God creates creatures in the world, with their respective names, attributes, and functions. Likewise, there are men and women, both of them are created with different names, different characteristics, and different functions. However, the differences do not mean that it creates different levels between men and women, but so that they can be worked together in in complementing each other in life.

\subsection{Leadership Traits in Javanese Culture}

One of leadership concepts that comes from Javanese culture is Asta Brata. Asta Brata is a teachings which was inherited from Hinduism. The teaching is adopted and used by Javanese people universally. Etymologically, the word of Asta Brata comes from Sanskrit. Asta means eight and Brata means practice or guideline (Suyami, 2008). Thus, Asta Brata can be interpreted as eight guidelines for everyone who want to be a good leader.

The word of Asta Brata comes from Manawa Dharma Sastra, one of Hinduism holy book that written in Sanskrit. The book states that a king must act based on characteristic of eight gods that are mentioned in Asta Brata (Pudja and Sudharta, 2003).

In essence, Asta Brata contain eight teachings of leadership behavior that symbolized by characteristic of gods which are personification of nature, namely: Surya (sun), Candra (moon), Kartika (star), Angkasa (sky), Bayu (wind), Samudra (sea), Agni (fire), and Pertiwi (earth). The characteristic of gods in Asta Brata are symbolization of elements of nature, which are manifested by Javanese people as leadership traits. Through Asta Brata's teachings, leaders are taught to emulate the nature traits into their behavior when leading a society (As'ad, Anggoro, and Virdanianty, 2011).

The explanations of eight leadership traits that refer to the nature traits are as follows (see As'ad, Anggoro, and Virdanianty, 2011).

\section{a. Sun/ Surya}

The sun has characterisctic for emitting bright rays and giving energy to all creatures of his shines. Based on character of the sun, a leader should enlighten and provide energy or welfare to his/ her people. 


\section{b. Moon/ Candra}

The moon has character of emitting a shady light in dark of night. The soft moonlight will be able to grow enthusiasm and hope in darkness. Based on characteristic of the moon, a leader should be able to provide encouragement or motivation to raise enthusiasm and hope of his/ her people, especially when they face economic difficulties and disasters.

\section{c. Star/ Kartika}

The star has a characteristic fixed in its place and does not change. This causes it useful for sailors and fishermen for guiding of directions when they in sailing across the oceans and when they returning to land. By taking characteristic of the star, a leader should be able to give instruction and advice to his/ her people. So, his/ her people can do their task without false or wrong ways.

\section{d. Sky/ Akasa/ Angkasa}

The sky has a character of wide and infinite, so it can accommodate whatever comes to it. Referring to characteristic of the sky, a leader should has extended knowledge. So, he/ she able to provide input and solutions to solve problems that are faced by people.

\section{e. Wind/ Bayu}

The wind has a character that always being everywhere, regardless of place and filling all spaces. Referring to character of the wind, a leader should be close to his/ her people, regardless of their degree and dignity. So, he/ she know situation of his/ her people and their desires. Thus, he/ she able to understand and absorb aspirations from people.

\section{f. Ocean/ Samudera}

The ocean is a place for compilation of water that flows from mountains, past through rivers, and disembogue into seas. The ocean has characteristic for cleaning the dirt of water that comes from its river estuaries. So, in the ocean the water will evaporating into the air and becoming rainwater. The rainwater becomes cool and refreshing water. By taking characteristic of the ocean, a leader should be able to accept criticism from his/ her people wisely and provide answers and soothing actions for their criticisms.

The ocean in a little and limited volume is called Apah or water. So, water can be represented symbol of the ocean.

\section{g. Fire/ Agni}

The fire has characteristics to burn up and destroy everything that comes and in contact with it. By taking character of the fire, a leader should be able to assertive, dignified, and brave to uphold truth and justice indiscriminately. He/ she must dare to punish someone who doing wrong or criminal and give reward to someone who doing right and meritorious.

The very large and unlimited number of fire is a huge fire from under the earth. Just a little part of it comes out to the earth's surface through volcanos. So, volcanos can be represented symbol of the fire.

\section{h. Land/ Pertiwi}

The earth has characteristics to give fertility generously and accepting waste and dirt that are bestowed upon it. Then, the earth cultivating them to be good materials again. Referring to characteristic the earth, a leader must have a generous, accepting all his/ her people with all 
their differences, such as: customs, religion, character, and so on. All differences of his/ her people that have potential to be conflict are managed and united again in togetherness.

\section{Discussion}

\subsection{Masculinity and Femininity Aspect from Asta Brata}

Based on explanation Asta Brata's teaching, all of characteristics of leadership of deities can be divided into two aspects, namely masculine and feminine. Masculine aspects of leadership are found in characteristics of Surya (sun), Angkasa (sky), Bayu (wind), and Agni (fire), while feminine aspects of leadership are found in Kartika (star), Candra (moon), Samudra ( ocean), and Pertiwi (land).

Why does aspect of leadership of a deity can be categorized as masculine, while other deity can be categorized as feminine? The answer is all of them can be traced in Javanese philosophies, that some of characterisctics of nature objects in Asta Brata are complementary in dualities. The concept of duality is two things that are mutually exclusive in life, both phisically and abstract. Duality of phisically, for example: day-night, light-dark, life-death, old-young, male-female, rich-poor, and so on. Duality of abstract, for example: right-wrong, good-bad, cause-effect, perfect-defect, happiness-suffering, hate-love, and so on. Likewise, the eight of leadership traits in Asta Brata's teaching, some of them are complementary aspects of duality.

The duality aspects of some of the leadership traits in Asta Brata teaching are follows.

a. Duality of Pertiwi-Angkasa

Javanese society has a concept of duality of Pertiwi-Angkasa, namely "Ibu Pertiwi-Bapa Angkasa" (Land as a mother and Sky as a father). It means if all of creatures and live in the earth or land are lived and nurtured by Pertiwi or land in where they live. Creatures that living in the earth are also protected by Angkasa or sky, from extraterrestrial objects that will fall to the earth, such as asteroids and meteors. These extraterrestrial objects fail to penetrate the atmospheric layers in sky. If there the extraterrestrial objects fall into the earth, it make a very big disaster for all life in the earth. Angkasa also has a ozone layer of atmosphere that protects from radiation of sunbeam which is harmful to lives/ creatures

Due to the duality of Pertiwi-Angkasa, in this case Javanese people firmly views that Pertiwi is considered to have a feminine aspect, i.e. give a living. So, Pertiwi is being personified in figure of a woman (which is marked by her mention, "Ibu/ mother". Conversely, Angkasa is considered to have a masculine aspect, because his task for protecting. So, Angkasa is personified in a male figure (which is marked by his mention "Bapa/ father").

b. Duality of Surya-Candra

Javanese society have a concept of day and night as an inseparable part of existence of Surya (sun) and Candra (moon), because the sun appears during the day, while the moon appears in the night. The moon with her dim and cool light is personified in a female figure. So, she is called Dewi Candra or Moon Goddess. On the other hand, the sun with his very strong light that make our eyes dazzle, and make the air getting hot, is personified in male figure, and commonly referred as Dewa Surya or Sun God.

Why the moon is personified as a feminine aspect is shown by number of parents who give their daughters names that mean "moon" also, such as: candra, wulan, ratih, sitaresmi, and others. On contrary, the sun is considered to represent masculine aspect, is shown by number 
of parents who give their sons names that mean "sun", such as: surya, raditya, bagaskara, sasangka, and others.

c. Duality of Segara-Gunung (Duality of Apah-Agni)

Javanese society have a concept of Segara-Gunung, that means "ocean and mount". The existence of mount and ocean is very important to create water and air circulation, for making harmony and welfare of creatures who lives on the land. The existence of mount and ocean causes air blow from the ocean to the mount during the day, then turn from the mount to the ocean at night due to differences in air pressure. The air that is moved over the oceans also carries water vapor from it. After moving towards the mount, it getting cools and turn down to the land as rainwater. The rainwater that falls on tops of the mount, seeps into the body of the mount and comes out again through springs on its slopes, becoming rivers that flow through valleys, lowlands, and finally go to disembogue, back into the sea. As long as the natural cycle occurs without any disturbance, so the harmony of lives on the land will always be maintained.

In concept of Javanese world view, the ocean is personified in figure of a woman, namely Nyi Roro Kidul or Ratu Laut Selatan (Queen of South Ocean). The other hand, the mounts, because of their dashing appearance, towering into the sky, and with dignity, they are personified in male figure. This is why, each mount has a masculine name to personify his appearance, such as: Eyang Lawu (Grandfather Lawu), Eyang Merapi (Grandfather Merapi), and others.

Furthermore, what is the relationship between duality of Segara-Gunung (ocean and mount) with Apah (water) and Agni (fire)? As people known, the ocean is a place for hold a very huge volume of water. On the other hand, many mounts that occur and grow up on the land because activity of "fire that break out from under the earth". The "fire that break out from under the earth" appears with volcanic materials, and make mound on that gets higher and higher, finally becomes a mount. Thus, Apah and Agni (water and fire) are "dualities in micro volume" of ocean and mount.

Like the oceans, water (and places that formed by water, such as rivers, lakes, springs) are also personified in figure of women, because of their characteristic of cool and refreshing for all of life. As an illustration, many rivers in India are personified in figures of "goddesses", and are given female names, such as: Ganges, Yamuna, Godesvari, Saraswati, and others.

In contrast to water, fire has characteristic to make heat and burning whatever gets his way. But fire is also useful for turning food into ripe. Thus, fire is personified in male figure, namely God Agni.

d. Kartika as a Feminine Aspect and Bayu as a Masculine Aspect

In contrast to the duality of Pertiwi-Angkasa, Surya-Candra, and Segara-Gunung in Asta Brata's teachings, it seems that Kartika (stars) has no duality relationship with Bayu (wind). However, basically Javanese people consider that the stars represent to feminine characteristics, because of their dim light and unchanging position in the sky. So, the stars become "silent directions", especially for fishermen and sailors when sailing the ocean. Why the stars in the sky are personified in figure of women is also shown by number of parents who give their daughters names that mean "star", compared to sons, such as: bintang, lintang, kejora, kartika, and others.

On the contrary, the wind is considered to represent masculine aspect because his power can destroy everything in his way. Just like names that mean stars, which are mostly given to girls, 
names that have the meaning of "strong of wind" are also generally given to boys, such as: topan, lesus, halilintar, bayu, guruh, wayu, and others.

\subsection{Asta Brata's Teaching is The Balancing of Leadership in Masculinity and Femininity Aspect}

Based on the explanation above, it can be seen that the leadership traits that taught in Asta Brata actually show the balancing of masculinity and femininity aspects. The balance of the two aspects can be illustrated in the following chart.

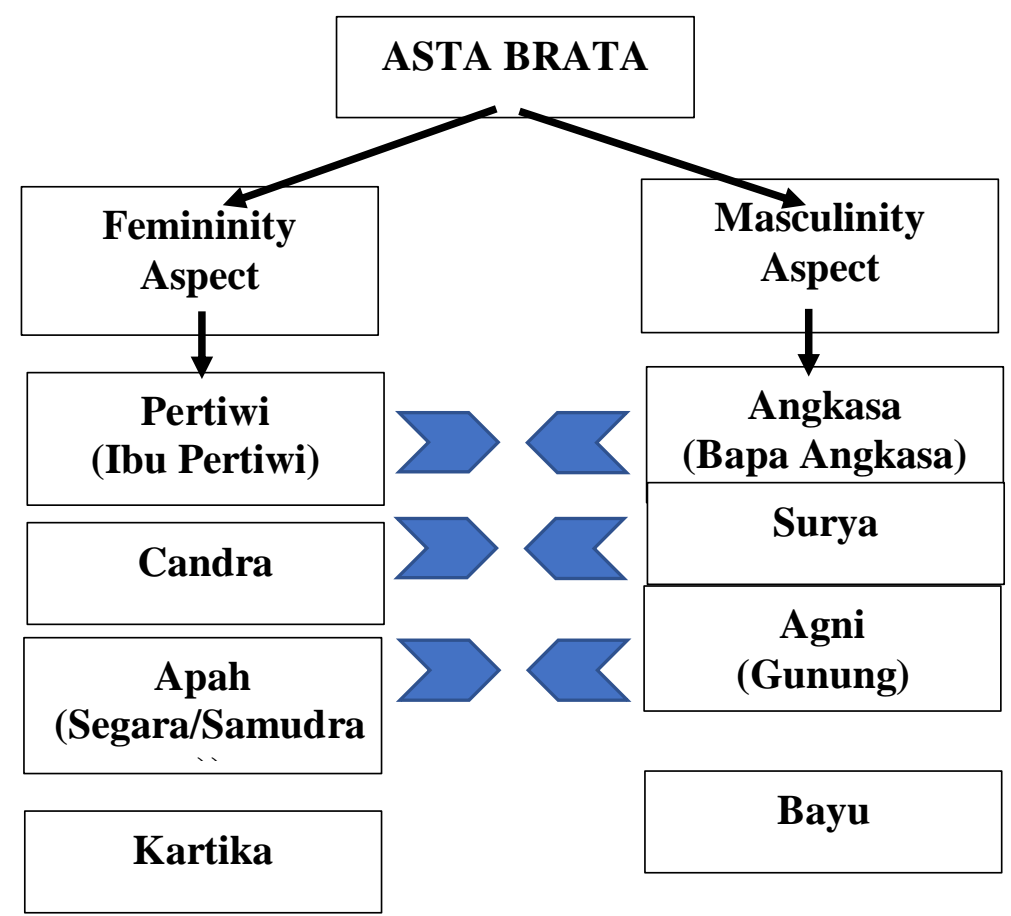

Annotation:

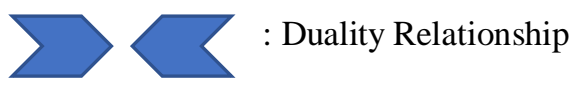

Based on the explanation above, it can be seen that both in Hinduism and Javanese perspective, it does not a matter if a woman becomes a leader of a society. Asta Brata's teachings teach that leaders must internalize themselves in order to have the eight charatcter of objects that exist in nature as guide to be qualities of leadership. The thing that distinguishes between women and men in leadership is only their leadership style. Women will tend to carry out a leadership style according to feminine aspects, while men tend to adopt a leadership style according to masculine aspects of Asta Brata. The difference style also explains why, in general, women who heads of regional governments still do not lose their feminine traits. 
Their leadership style can be accepted by their society, without having to change their personality to become masculinity, like men leadership.

\section{Conclusion}

The leadership of women in a society is still considered inappropriate for some people because women are considered not to have leadership traits, such as: harsh, firm, strong, courageous, feared by opponents, and so on. However, in historical reality, there were always women leaders, both in Nusantara and in other parts of the world. In modern era, there are always appear women who become regional leaders, starting from regency/ municipality, province, up to country. Even though they become regional heads or even president.

There are many perspectives that develop in society, that in order to be accepted as leaders of a society, women leaders must change their characteristics to suit the demands of leadership traits that are identical to masculinity. However, in reality, even though they become regional heads or even presidents, women leaders still do not lose their characteristics as women, such as: graceful, humanistic, maternity, doing by feelings, etc., which are not considered suitable characteristics for leading a society. The teaching of Asta Brata shows that to be a leader of a society does not have to be filled by masculine traits, but also feminine traits.

The qualities of good leadership in the teachings of Asta Brata are symbolized by characteristics of objects in nature which are personified as deity, namely: Surya, Candra, Kartika, Angkasa, Bayu, Samudra, Agni, and Pertiwi. The eight leadership traits reflect duality (two opposing but complementary aspects), namely masculine and feminine. The masculine aspect of leadership is found in characteristic of Surya (sun), Angkasa (sky), Bayu (wind), and Agni (fire). Meanwhile, the feminine aspect of leadership is found in characteristics of Kartika (star), Candra (moon), Samudra (ocean), and Pertiwi (land/ earth). Refers to the duality, Pertiwi complements each other with Angkasa, Candra with Surya, and Samudra (or Apah) with Agni (or Gunung). Kartika is not a duality to Bayu. Nevertheless, Kartika represents feminine character, while Bayu represents masculine character.

The masculine aspect of leadership naturally exists in characteristics of men who are leaders of a society. Likewise, the feminine aspect of leadership is naturally found in characteristics of women who are leaders of a society. Based on Asta Brata's teachings, it can be concluded that women have equality with men to become leaders of a society. However, women's leadership styles are different from men, because the feminine aspect of leadership is more dominant than masculine aspect.

\section{References}

As'ad, Mohammad. Wahyu Jati Anggoro, Mariana Virdanianty. 2011. "Studi Eksplorasi Konstrak Kepemimpian Model Jawa: Asta Brata”. Jurnal Psikologi. Volume 38, No. 2, Desember 2011, pages. $228-239$.

Delapan Sifat Benda Alam untuk Cermin Kepemimpinan. https:// sejarahharirayahindu.blogspot. com/2011/12/asta-brata.html, accessed 2 September 2020

Deskripsi Konsep Dualitas. 24 Juni 2015. https://www.kompasiana.com/ ujangbandeung/ 5528134c6ea83474298b4571/deskripsi-konsep-dualitas, accessed 3 August 2020.

Holsti, O. R. 1969. Content Analysis for the Social Sciences and Humanities. Wesley: M.A. Addison.

Lasswell, H.D., Daniel L. \& Ithiel de S.P. 1952. The Comparative Study of Symbols. Stanford, CA: Stanford University Pres

Nasution. 1996. Metode Penelitian Naturalistik Kualitatif. Bandung: Tarsito. 
Nurhadi, Nando. 2016. Bapa Angkasa Ibu Bumi Pertiwi: Harmonisasi dan Manunggaling Kawula Gusti. https://nandonurhadi.wordpress.com/ 2016/12/31/bapa-angkasa-ibu-bumi-pertiwi-harmonisasimanunggaling-kawula-gusti/, accessed 3 July 2020.

Pudja, Gede. dan Tjokorda Rai Sudharta. 2003. Manawa Dharmasastra (Manu Dharmasastra) atau Weda Smṛti: Compendium Hukum Hindu. Jakarta: Pustaka Mitra Jaya.

Puspa, Ida Ayu Tary. 2012. "Pemimpin Perempuan yang Balinese dalam Perspektif Hindu". Jurnal Studi Jender Srikandi, Volume 1, November 2012.

Putri, Risa Herdahita. 2017. Para Sultanah di Kesultanan Aceh. 16 Desember 2017. https://historia.id/kuno/articles/para-sultanah-di-kesultanan-aceh-P1BJ0, accessed 25 August 2020.

"Studi Kepustakaan", Pengertian, dan (Tujuan-Peranan-Sumber-Strategi). https://www.gurupendidikan.co.id/studi-kepustakaan-pengertian-tujuan-peranan-sumber-strategi/, accessed 1 April 2020.

Sugiyono. 2008. Metode Penelitian Kuantitatif Kualitatif dan R \&D. Bandung: Alfabeta.

Suyami. 2008. Konsep Kepemimpinan Jawa dalam Ajaran Sastra Cetha dan Astha Brata. Yogyakarta: Kepel Press.

Tumpi Readhouse Budaya. 2016. Dasanama, Padanan Kata dalam Bahasa Jawa. 2 Mei 2016. https://tumpi.id/dasanama-padanan-kata/, accessed 5 Agustus 2020.

Wahab, Abdul Azis. 2008. Anatomi Organisasi dan Kepemimpinan Pendidikan. Bandung: Alfabeta. 